\title{
Use of Combination of Life Cycle Cost Analysis and Life Cycle Energy Analysis for Decision Making In A Green Building in India
}

\author{
"Shashank Borade ${ }^{1}$, Sunil Pimplikar ${ }^{2}$ \\ ${ }^{1}$ Student of ME (Construction \& Management), Maharashtra Institute of Technology, Pune, Maharashtra, India \\ ${ }^{2}$ Head of Department, Civil Engineering, Maharashtra Institute of Technology, Pune, Maharashtra, India \\ Corresponding Author: Shashank Borade
}

\begin{abstract}
The aim of this study is to establish life cycle cost and energy analysis for a sample green building. A school building with green features was selected and life cycle analysis was performed. The material quantity helped in calculating embodied energy values while the electricity bill gave operational energy values. Cost analysis was also done for construction and operational stages of building. The aim of study is to determine LCE and LCA values for the building. The study helped in determining how a green building will incur savings in energy and cost through its life cycle.
\end{abstract}

Key Words: embodied energy, operational energy, life cycle energy analysis, life cycle cost analysis, green building, etc.

\section{Introduction}

Life Cycle Energy Analysis is a tool for systematic evaluation of environmental aspects of product or service through all stages of its life cycle. In construction sector, energy consumption occurs during construction as well as maintenance and operation stages of a project. Application of green building techniques during construction stage can significantly reduce consumption during operation and maintenance stages. However these techniques also need to be cost effective. Hence life cycle cost analysis needs to be done to determine the economic feasibility and help in decision making. LCA can be used as a tool to assess effectiveness of a green building technique before its installation. The aim of the paper is to present a methodology to jointly carry out life cycle cost as well as energy analysis to determine if green building measure should be applied or not.

\section{Literature Review}

According to United Nations Environment Programme (UNEP) [1] buildings use about $40 \%$ of energy, $25 \%$ of global water, $40 \%$ of global resources, and they emit approximately $1 / 3$ of GHG emissions. Residential and commercial buildings consume about $60 \%$ of world's electricity. Energy consumption in buildings can be reduced by 30 to $80 \%$ using proven and commercially available technologies.

Mohamad Monkiz Khasreen, Phillip F.G. Banfill, and Gillian F. Menzies in their paper "Life-Cycle Assessment and the Environmental Impact of Buildings: A Review" [2] studied LCA from a buildings perspective. The paper highlights the need for use of LCA within the building sector, and the importance of LCA as a decision making tool. The authors highlight the problems of lack of internationally comparable and agreed data inventory and assessment methodology which hinder the application of LCA within the building industry. In the conclusion it summarizes the limitations and opportunities in LCA.

I Sartori, A.G. Hestnes in their paper "Energy use in the life cycle of conventional and low-energy buildings: A review article" [3] found out that operational is major part of total energy consumption of a building. It showed that design of low-energy buildings gives a net benefit in total life cycle energy demand but with an increase in the embodied energy.

Roger Fay, Graham Treloar and Usha Iyer-Raniga in their paper "Life-cycle energy analysis of buildings: a case study" [4] gave a formula for calculation of life cycle energy calculation where LCE is sum total of embedded energy (initial and recurrent) and operational energy. The authors did a case study on a green home in Australia. The paper stressed on decision making based on LCEA which strikes a balance between embodied and operational energy. 


\section{Theoretical Contents}

Life cycle analysis (LCA) - it is a process whereby the material and energy contents of a system are quantified and evaluated.

Life cycle energy analysis (LCEA) - is an approach that accounts for all energy consumption of a building in its life cycle.

Operational energy - energy consumed during the operational stage of building for purposes like lighting, heating water, electrical appliances, heating, ventilation, air-conditioning and energy used for building maintenance. Operational energy largely varies on the level of comfort required, climatic conditions and operating hours.

Embodied Energy - energy essential for extraction, processing and acquiring construction materials, transportation of the material and energy needed directly on-site. Embodied energy largely depends on the type of the materials used, primary energy sources, and efficiency of conversion processes in making building materials and products.

Demolition energy - it is energy required at the end of buildings' service life to demolish the building and transport the waste material to landfill sites and/or recycling plants.

Life cycle energy (LCE) - Life cycle energy of the building is the sum of the all the energies incurred in its life cycle.

Life-cycle cost analysis (LCCA) - It is a tool to determine the most cost-effective option among different competing alternatives to purchase, own, operate, maintain and, finally, dispose of an object or process, when each is equally appropriate to be implemented on technical grounds.

Construction Cost - Cost incurred for building construction. It includes various costs such as cost of structure of building, interior and finishes cost and Architect and consultants' fees, etc.

Operational Costs - Building requires energy throughout its lifespan for purposes such as lighting, heating water, electrical appliances, cooking, heating, ventilation, air-conditioning and energy used for building maintenance. The cost of energy (in the form of electricity, gas, etc.) is known as operational cost.

Recurring Costs/Replacement Costs - All the building components do not have a service life equal to life of building structure. Those materials which have life less than building life are replaced time to time. Replacement cost is cost incurred to replace such materials during the entire lifespan of the building.

Maintenance and Repair Costs - It is the cost incurred on regular and periodic maintenance and repair of building and its components during the entire life of building.

Life Cycle Cost/Total Costs - LCC is sum total of all the money that is spent on building in its lifetime in the form of initial construction cost, operational cost, replacement cost, repairs \& maintenance cost and demolition cost.

\section{Objectives}

1. To perform life cycle energy analysis and life cycle cost analysis of a sample green building. Determine Life Cycle Energy and Life Cycle Cost for the same building.

2. Determine LCE per unit area of building.

3. Determine energy and cost saving for the building due to green design compared to conventional design for the same building. Find out how life cycle cost analysis can be used in decision making regarding green building.

\section{Methodology}

A school building in Pune (Avasara Academy) with enough green building measures was selected for the study. Data was collected for this project and questionnaires were asked to related persons. The analysis of data helped in determining life cycle energies and the costs involved in the construction and operational stages of building. The embodied and operational energies were calculated. From the questionnaires collected savings in energy and thereby costs due to use of green measures were calculated. All these helped in establishing Life Cycle Energy and Cost Analysis for the said building and thus help in decision making.

\section{Case Study}

Name of Project - Avasara Academy Building No. - 3 (Girls School)

Location - Pune, India

Building selected - Building No. 3 (4 storey)

Work Progress - Building 3 was completed and was in operational stage i.e. was used as a school.

Eco-friendly features installed on site:

- Rooftop Solar for lighting and heating

- Natural Ventilation (Hume pipes and solar

- Building orientation to maximize daylight.

chimneys) 
- Recycled doors and windows

- Recycled flooring

- Rain Water harvesting.

\section{Data Collection}

Data collected was general information of project, Bill of Quantities of Building 3, drawings such as floor plans, sectional elevations, etc., monthly electricity consumption bills, cost of project, information regarding green building features of the building and general questionnaires.

\section{Data Analysis}

The above data collected helped to achieve the objectives. From the BOQ, material quantity of each building material (e.g. steel, concrete) was taken out and was used to calculate embodied energy contained in it. These quantities were then multiplied by embodied energy intensities for unit quantities. The embodied energy intensity values were taken from Inventory of Carbon and Energy (University of Bath, UK) [5]. Also cost of initial construction was taken from BOQ. For calculation of later repetitions of building, the life of material was assumed. The building life was assumed to be 50 years. The life of solar was assumed to be 25 years. Thus it will have 2 repetitions in 50 years lifespan. In the given building, as doors \& windows and broken stone and marble pieces are reused from another project, they have zero embodied energy. The embodied energy values are given in Table 1. For operational energy, electricity consumption records collected over a period of 6 months helped in determining operational energy demand of the building throughout its life cycle. The secondary energy thus obtained was multiplied by primary conversion factors to convert into primary energy i.e. it accounts for the energy spent in generating energy and losses incurred during extraction, transmission and distribution of energy [4]. Also LPG used for cooking was measured and added to the operational energy. It was assumed that no change in building use and structure is made i.e. building and its use remains same throughout lifespan. Hence, operational energy remains same throughout lifecycle i.e. energy consumed in $1^{\text {st }}$ year will be repeated for next 50 years. Operational energy is shown in Table 2.

Table 1: Embodied Energy Calculations

\begin{tabular}{|c|c|c|c|c|c|c|c|c|c|}
\hline $\begin{array}{l}\text { Sr. } \\
\text { No. }\end{array}$ & Material & Unit & Quantity & $\begin{array}{c}\text { Density } \\
(\mathrm{kg} \text { per } \\
\left.\mathrm{m}^{3}\right)\end{array}$ & $\begin{array}{l}\text { Quantity } \\
\text { in } \mathrm{kg}\end{array}$ & $\begin{array}{c}\text { Energy } \\
\text { Intensity } \\
\text { (MJ per kg) }\end{array}$ & $\begin{array}{c}\text { Life of } \\
\text { material } \\
\text { (Years) }\end{array}$ & $\begin{array}{c}\text { No. of } \\
\text { repetitio } \\
n\end{array}$ & $\begin{array}{c}\text { Embodied } \\
\text { Energy (MJ) }\end{array}$ \\
\hline \multirow[t]{4}{*}{1} & Concrete & & & & & & & & 6902862.00 \\
\hline & M25 & $\mathrm{m}^{3}$ & 625.00 & 2400 & 1500000 & 1.39 & 50 & 1 & 2085000.00 \\
\hline & M10 & $\mathrm{m}^{3}$ & 144.00 & 2400 & 345600 & 0.77 & 50 & 1 & 266112.00 \\
\hline & M40 & $\mathrm{m}^{3}$ & 120.00 & 2400 & & 6000 per $\mathrm{m}^{3}$ & 50 & 1 & 720000.00 \\
\hline 3 & Hume Pipes & per $m$ & 166.00 & 2400 & 500837 & 1.39 & 50 & 1 & 696163.15 \\
\hline 4 & Painting & $\mathrm{m}^{2}$ & 3405.00 & & & $\begin{array}{c}\text { 30.6 MJ per } \\
\mathrm{m}^{2}\end{array}$ & 7 & 8 & 833544.00 \\
\hline 5 & Plaster & $m^{2}$ & 220.00 & 1120 & & 1.80 & 50 & 1 & 4435.20 \\
\hline 6 & $\begin{array}{c}\text { AAC Blocks } 250 \\
\text { mm }\end{array}$ & $\mathrm{m}^{2}$ & 2250.00 & 750 & & 3.50 & 50 & 1 & 1476562.50 \\
\hline 10 & Granite & $\mathrm{m}^{3}$ & 5.50 & 2800 & 15400 & 7.50 & 50 & 1 & 115500.00 \\
\hline 11 & Ceramic & $\mathrm{m}^{3}$ & 2.20 & 2000 & 4400 & 9.00 & 25 & 2 & 79200.00 \\
\hline 12 & Broken Stone & $\mathrm{m}^{3}$ & 12.94 & 2300 & 29762 & 1.00 & 25 & 2 & 0.00 \\
\hline 13 & Wooden Doors & nos. & 46.00 & & & 286 per unit & 50 & 1 & 0.00 \\
\hline 14 & Wooden Windows & nos. & 37.00 & & & 286 per unit & 50 & 1 & 0.00 \\
\hline 15 & $\begin{array}{l}\text { Plywood Flush } \\
\text { Door Panels }\end{array}$ & $\mathrm{m}^{2}$ & 70.00 & 540 & 37800 & 15.00 & 5 & 10 & 56700.00 \\
\hline 16 & Solar Panels & $\mathrm{m}^{2}$ & 105.60 & & & 4750 per $\mathrm{m}^{2}$ & 25 & 2 & 1003200.00 \\
\hline 17 & PVC Pipes & $\mathrm{kg}$ & 729.22 & & 729 & 67.50 & 50 & 1 & 49222.44 \\
\hline 18 & Glass & $\mathrm{m}^{2}$ & 287.00 & 2500 & 5740 & 15.00 & 50 & 1 & 86100.00 \\
\hline
\end{tabular}

The Life Cycle Energy was calculated by adding embodied and operational energy. Demolition energy was not considered as it is very low [4]. LCE is shown in Table 3.

Cost of construction of building was taken from BOQ. The cost for 1 year of operational energy was obtained. The costs of operation were calculated for 50 years by forecasting based on the projected inflation rates (6\% inflation rate as per RBI monetary policy) and discount rates. Also maintenance and recurring costs 
were calculated. Life Cycle Cost was calculated by adding all above costs. Total savings in life cycle cost was calculated by comparing it to the same building if had been designed in a conventional way. Based on these it was determined how green building is economic and environment friendly in long run compared to conventional one. It is shown in Table 4.

Table 2: Operational Energy Calculations

\begin{tabular}{|c|c|c|c|c|c|c|c|}
\hline $\begin{array}{c}\text { Sr. } \\
\text { No. }\end{array}$ & Source & Unit & $\begin{array}{c}\text { Yearly } \\
\text { Consumption }\end{array}$ & $\begin{array}{c}\text { Energy } \\
\text { Conversion } \\
\text { Factor to MJ }\end{array}$ & $\begin{array}{c}\text { Primary } \\
\text { Energy } \\
\text { Multiplication } \\
\text { Factor }\end{array}$ & $\begin{array}{c}\text { Energy } \\
\text { consumed in } \\
1 \text { Year (MJ) }\end{array}$ & $\begin{array}{c}\text { Energy consumed in 50 } \\
\text { Years (MJ) }\end{array}$ \\
\hline 1 & Electricity & $\mathrm{kWh}$ & 29418 & 3.6 & 3.5 & 370666.8 & 18533340 \\
\hline 2 & $\begin{array}{c}\text { LPG Cooking } \\
\text { Gas }\end{array}$ & $\mathrm{kg}$ & 1824 & 49 & 1.4 & 125126.4 & 6256320 \\
\hline & & & & & & Total & 24789660 \\
\hline
\end{tabular}

Table 3: Total Energy Values

\begin{tabular}{|c|c|c|c|}
\hline & MJ & TJ & $\%$ \\
\hline Total Embodied Energy & 13971855.29 & 13.97 & 36.05 \\
\hline Total Operational Energy & 24789660.00 & 24.79 & 63.95 \\
\hline Total Energy/Life Cycle Energy & 38761515.29 & 38.76 & 100.00 \\
\hline
\end{tabular}

Table 4: Life Cycle Cost

\begin{tabular}{|c|c|c|c|c|c|}
\hline Sr. & Type of Design & \multicolumn{4}{|c|}{ Life Cycle Cost (Rs) } \\
\cline { 3 - 6 } No. & & $\begin{array}{c}\text { At discount rate } \\
6 \%\end{array}$ & $\begin{array}{c}\text { At discount } \\
\text { rate } 8 \%\end{array}$ & $\begin{array}{c}\text { At discount } \\
\text { rate } 10 \%\end{array}$ & $\begin{array}{c}\text { At discount } \\
\text { rate } 12 \%\end{array}$ \\
\hline 1 & For Green Design & 102597971 & 82088257 & 70627340 & 63316206 \\
\hline 2 & For Conventional Design & 152715769 & 114927552 & 93797560 & 80194753 \\
\hline & Difference in Cost & 50117798 & 32839294 & 23170219 & 16878547 \\
\hline & Percent Decrease in Cost for Green Building & $33 \%$ & $29 \%$ & $25 \%$ & $21 \%$ \\
\hline
\end{tabular}

\section{Conclusion}

Combination of LCCA and LCEA can be used for decision making. This will help in determining practical solutions which help in energy as well as cost saving. It was found out that measures during construction stage bring significant returns in operational stage. The Life Cycle Energy of building is 38 TJ. Had it been designed in a conventional way, the LCE would have been 70 TJ. Thus the building through its green approach has reduced its LCE by $46 \%$. This is a great achievement in terms of environment.

The LCE of the said building is $38 \mathrm{TJ}$ for a built-up area of $2580.6 \mathrm{~m}^{2}$ Thus the LCE per unit area of building is $15.2 \mathrm{GJ} \mathrm{m}^{2}$ throughout the entire lifespan of building (50 years). The same energy when converted to $\mathrm{kWh}$ will be $4172.32 \mathrm{kWh} / \mathrm{m}^{2}$. For 1 year the LCE will be $0.3 \mathrm{GJ} / \mathrm{m}^{2}$ or $83.45 \mathrm{kWh} / \mathrm{m}^{2}$.

The Life Cycle Cost of building is reduced by about 21 to $33 \%$; depending on discount rate considered for discounting future cash flows. Even at minimum value of $21 \%$, the client has incurred significant savings in life cycle terms. Thus green building measures are not necessarily costly. They reduce operational costs in a big way at a meager increase in initial costs. Thus client decision to go ahead with the green building measures is proved correct. Thus LCEA and LCCA helps in decision making regarding green building.

Website:

\section{References}

[1] www.unep.org/resourceefficiency/buildings ( website of United Nations Environment Programme) Date of Access - 03 April, 2017 Papers:

[2] Mohamad Monkiz Khasreen, Phillip F.G. Banfill, and Gillian F. Menzies, "Life-Cycle Assessment and the Environmental Impact of Buildings: A Review' Sustainability, Page no. 674-701,doi: 10.3390, (2009)

[3] I. Sartori , A.G. Hestnes, "Energy use in the life cycle of conventional and low-energy buildings: A review article" Science Direct, Energy and Buildings 39, Page no. 249-257, (2007)

[4] Roger Fay, Graham Treloar and Usha Iyer-Raniga, "Life-cycle energy analysis of buildings: a case study", Building Research \& Information, 28(1), Page No. 31-41, (2000)

[5] Prof. Geoff Hammond, Craig Jones, "Inventory of Carbon and Energy", University of Bath, Version 1.6a, (2008); Page No. 10 to Page No. 15.

\footnotetext{
Shashank Borade. "Use of Combination of Life Cycle Cost Analysis and Life Cycle Energy Analysis for Decision Making In A Green Building in India." IOSR Journal of Mechanical and Civil Engineering (IOSR-JMCE) 14.4 (2017): 49-52.
} 